J. Perinat. Med. 14 (1986) 243

\title{
Placental transfer of parathyroid hormone
}

\author{
Svetla Balabanova ${ }^{1}$, Thomas Lang ${ }^{1}$, Alfred S. Wolf ${ }^{2}$, Ivo Henrichs ${ }^{1}$, Janos \\ Homoki $^{1}$, Gerhard Gaedicke ${ }^{1}$, Ulrich Vetter ${ }^{1}$, and Walter M. Teller ${ }^{1}$
}

${ }^{1}$ Department of Pediatrics and ${ }^{2}$ Department of Obstetrics and Gynecology, University of Ulm, Fed. Rep. Germany

\section{Introduction}

The permeability of the placenta for parathyroid hormone (PTH) was first postulated by MEINERT 1898 [19]. He and later on BRONSKY [7] reported relief of tetany during pregnancy in women with hypoparathyroidism prior to conception. The authors proposed that the relief of tetany was by transfer of fetal PTH to the mothers.

The permeability of the placenta for PTH was studied in vivo in several animal experiments $[9,11,13,16,18,22,30]$. PTH transfer was observed, but the transfer was inconsistent and the amounts of transferred hormone were very small. The authors concluded that PTH does not cross the placenta in either direction.

Recently we have reported that PTH (amino acids $35-84$ ) traverses the human placenta at term in both directions. These effects were studied in an in vitro placenta perfusion model [4]. The transferred PTH quantities (up to $5 \%$ of the perfused PTH) were determined radioimmunologically and consequently it was not possible to exclude that only PTH fragments or metabolites were transferred.

In this study we have investigated the placental transfer of three PTH fragments in vitro. The perfused and transferred fragments were identified by three different physiochemical methods.

\section{Curriculum vitae}

SVetla BALABANOva was born in 1929 in Sofia, Bulgaria. She studied chemistry at the University of Prague, Czechoslovakia. From 1962 to 1970 she worked in the Most Hospital in Czechoslovakia. Starting in 1974, she did her residency at the University of Ulm, West Germany. In 1982 she received

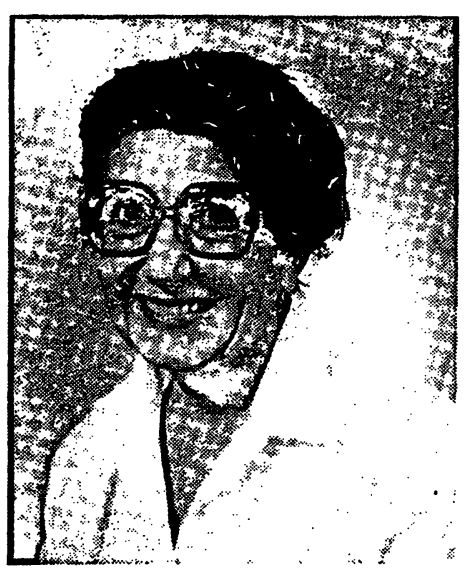
a Dr. rer. biol. hum. from the University of Ulm with a thesis on placental transfer of parathyroid hormone. At present she is employed at the Institute of Forensic Medicine, University of Ulm.

An abstract of this work has been published previously [5].

\section{Materials and methods}

\subsection{Placental perfusion}

Placentae at term were obtained immediately after delivery. A cotyledon approximately $3-4 \mathrm{~cm}$ as preparated for perfusion according to the method and the perfusion model developed by HeNRICHS and Wolf [14], which was a modification of the model of SCHNEIDER [27]. 
PTH extract was infused into the fetal artery (feto-maternal transfer) for 20 minutes. Perfusate samples from the maternal side (MS) and the fetal vein (FV) were taken at intervals of 3 and 5 minutes over a period of $40 \mathrm{~min}$ after the start of perfusion. Complete separation of samples from the maternal and fetal sides was proved by dextranblue added to the perfusate. Furthermore, PTH extract was infused into the intravillous space for $20 \mathrm{~min}$. Perfusate samples from fetal and maternal vein were taken as above. The PTH fragments assayed for the perfusion were: ${ }^{125} \mathrm{I}$-labelled $\left({ }^{*}\right)$ and nonlabelled bovine C-terminal (amino acids 35-84) fragment (Institut National des Radioelements, Belgium), ${ }^{125}$ I-labelled (*) and nonlabelled synthetic middle C-terminal (44-68) fragment (Paesel, Germany), and ${ }^{125}$ I-labelled (*) synthetic human C-terminal (amino acids 65-84) fragment (Bachem, Switzerland). The activities of the labelled fragments were $1 \mu \mathrm{Ci}$ for each experiment.

The transfer of the labelled fragments was determined by counting the activity in the samples collected at the opposite site. The transfer of nonlabelled hormone was determined by radioimmunoassays (35-84: Institut National des Radioelements, Belgium, 44-68: Paesel, Germany).

The identification of fragments was achieved as follows:

a) High-pressure-liquid chromatography (HPLC) (Waters Inc). Synchropak RPR $10 \mu, 100 \mathrm{~A}$ in $2504.6 \mathrm{~mm}$ stainless-steel columns (Bischoff, Germany) were used. Separation was carried out at $20^{\circ} \mathrm{C}$, with $0.1 \mathrm{~m}$ phosphate buffer ( $\mathrm{pH} 2.1$ ) as primary solvent and acetonitril as organic modifier at constant flow rate of $1 \mathrm{ml} / \mathrm{min}$ and $220 \mathrm{~nm}$ UV adsorbance. The fractions were collected and the radioactivity of each measured in the gamma counter.

b) Preparative-flat-bed electrofocusing (PEGG) was performed in a granulated gel (5 $\mathrm{ml} \mathrm{40 \%} \mathrm{Servalyt} \mathrm{pH} 2-11,5 \mathrm{ml}$ sample, $90 \mathrm{ml}$ distilled water). The separated zones were collected and their activity measured in the gamma counter.

c) Gel filtration (GF). For the gel filtration of sephadex columns G-25900 $16 \mathrm{~mm}$ (Pharmacia, Sweden) were used. The flow rate was $1.0 \mathrm{ml} / \mathrm{min}$ at $20^{\circ} \mathrm{C}$ in phosphate buffer $\mathrm{pH}$ 7.5. Fractions were collected at $2 \mathrm{ml}$. The activity in the collected fractions was measured. Dextranblue, cytochrome $C$ and vitamin $B$ were added as calibrating substances to each filtration.

\subsection{RIA for PTH}

The concentrations of PTH fragments 35-84 were measured by RIA of the C-terminal. The standard was bovine PTH, the antiserum was a rabbit antiserum directed against the C-terminal part (amino acids 35-84) of the molecule. The standard curve covers the range $0.3 \mathrm{ng} / \mathrm{ml}-12,5 \mathrm{ng} / \mathrm{ml}$. The intra- and interassay coefficients of variation were $7.2 \%$ and 10.2\%. RIA for PTH 44-68:

The standard was synthetic PTH, the antibody was prepared in the goat against the amino acids 44-68 part of the hormone. The lower limit of sensitivity was $0.05 \mathrm{ng} / \mathrm{ml}$. The intraassay coefficient of variation was $11.2 \%$.

\subsection{Patients}

Forty healthy pregnant women who were admitted to the University Maternity Hospital for delivery were studied. Informed consent was obtained from each. All infants were born at term by spontaneous vaginal delivery. Forty blood samples were obtained by venipuncture from mothers at delivery and from the umbilical cord by separate catheterization of the umbilical cord vein and artery. After centrifugation plasma samples were frozen at $-20^{\circ} \mathrm{C}$ until analyzed. The samples were collected from October 1981 through February 1982. Plasma samples of 169 normal adult volunteers (87 women and $82 \mathrm{men}$ ) ranging in age from 20 to 50 years were studied for reference. 


\subsection{Statistical methods}

Results were expressed as median and range. Data were statistically evaluated using the Wilcoxon test for paired samples and Student'ttest for comparison of individual values. Correlations (r) were tested by linear regression analysis.

\section{Results}

The transfer of ${ }^{125}$ I-labelled or nonlabelled PTH fragments was detected after 3 minutes of perfusion. The concentrations measured by RIA and/or counting of the radioactivity (CPM) rose during the perfusion up to $5 \%$ of the perfused concentration (figure 1). The retention times (rt) and isoelectric points (IP) of the perfused and transferred ${ }^{125}$ I-labelled PTH fragments, determined by GF, HPLC and PEGG respectively, were identical.

On GF analysis the eluted labelled PTH fragments $(35-84)^{*},(44-68)^{*}$ and $(65-84)^{*}$ with molecular weights (MWt) of 6300,3250 and 2450 respectively, showed positions which were consistent with the calibrating substances (dextranblue, cytochrom C and vitamin B with MWt of 2000000,12300 and 1355, respectively). The results of the different separation methods for three fragments are given in figure 2.

We observed up to a $67 \%$ degradation of the PTH hormone during the passage of the placenta (from fetal to maternal side and vice versa) (figure 3).

The median and ranges for plasma PTH (amino acids 35-84) of maternal venous, umbilical cord vessel samples and adult venous plasma samples studied as controls are demonstrated in the table I. PTH was detected in all 40 maternal and umbilical cord vessel plasma samples. The umbilical venous PTH concentrations were significantly lower than the arterial $(P<0.001)$. The median of the arterial and venous umbilical samples differed about $0.2 \mathrm{ng} /$ $\mathrm{ml}$. The fetal venous PTH values were signifi-
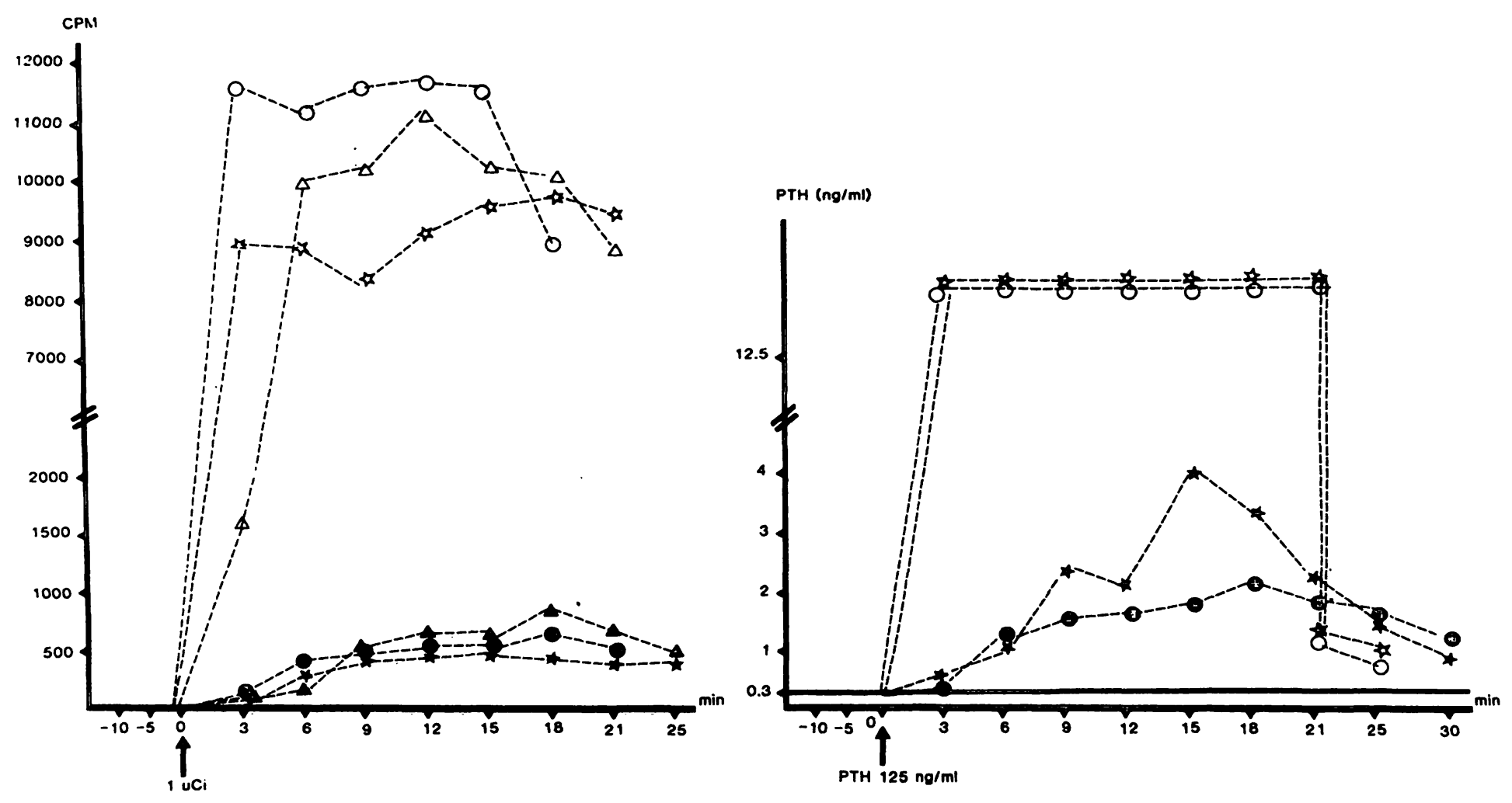

Figure 1. Feto maternal transfer of ${ }^{125}$ I-labelled $(35-84,44-68$ and $65-84)$ and non labelled (35-84 and 44-68) fragments. Perfused fragments 35-84 $\downarrow\lrcorner t, 44-68 \bigcirc 0,65-84 \Delta \Delta$. Transferred fragments: $35-84 \star \star, 44-68$ 0 and $65-84 \Delta \Delta$. 

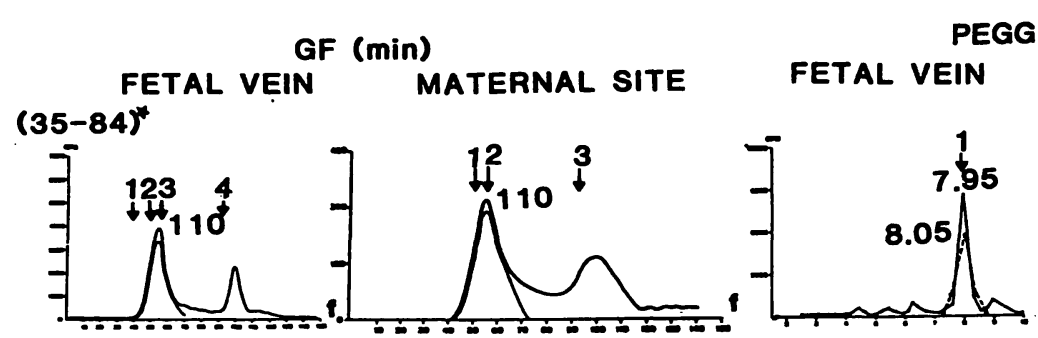

PEGG (pH)

HPLC (min)

MATERNAL SITE FETAL VEIN MATERNAL SITE

$(44-68)^{*}$
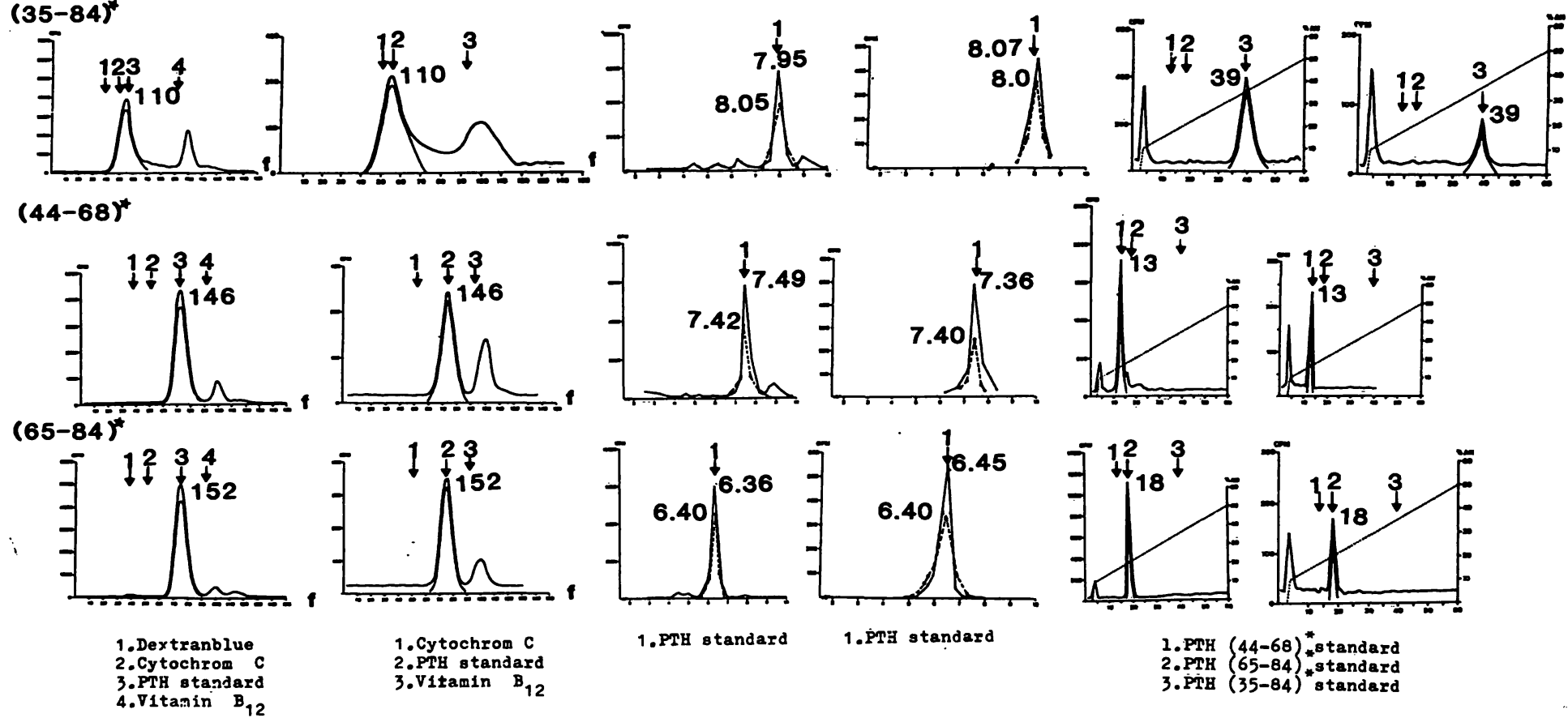

$$
\begin{aligned}
& \text { 1. Cytochrom C } \\
& \text { 2.PTH standard } \\
& \text { 3.Vitamin } B_{12}
\end{aligned}
$$
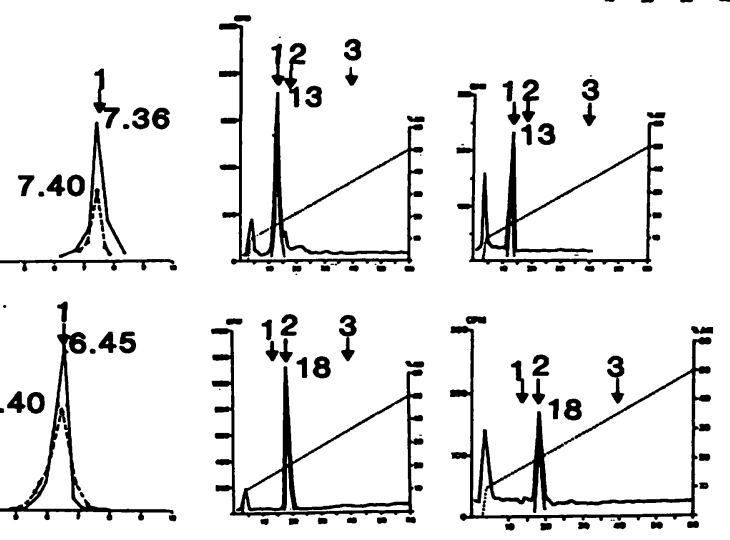

1.PTH standard

1.PTI standard 1.PTH $(44-68)$ * standard
2.PTH $(65-84)$ standard
3.PTH $(35-84)$ standard

Figure 2. Elution profiles after GF, PEGG and HPLC of I-labelled PTH fragments amino acids (35-84)*, (44-68)* and $(65-84) *$. The arrows indicate the retention times of substances added to each measurement as calibrating substances.

GF (gelfiltration): fetal vein: arrows 1. dextranblue, 2. cytochrom C, 3. PTH standards and 4. vitamin B 12. Maternal side: arrows 1. cytochrome C, 2. PTH standards and 3. vitamin B 12. PEGG (preparative flat bed electrofocusion): both fetal and maternal sides: arrow 1. PTH standard. HPLC (high-pressure liquid chromatography): both fetal and maternal side arrows 1 to $3 \mathrm{PTH}$ standards $35-84,44-68$ and $65-84$ respectively.
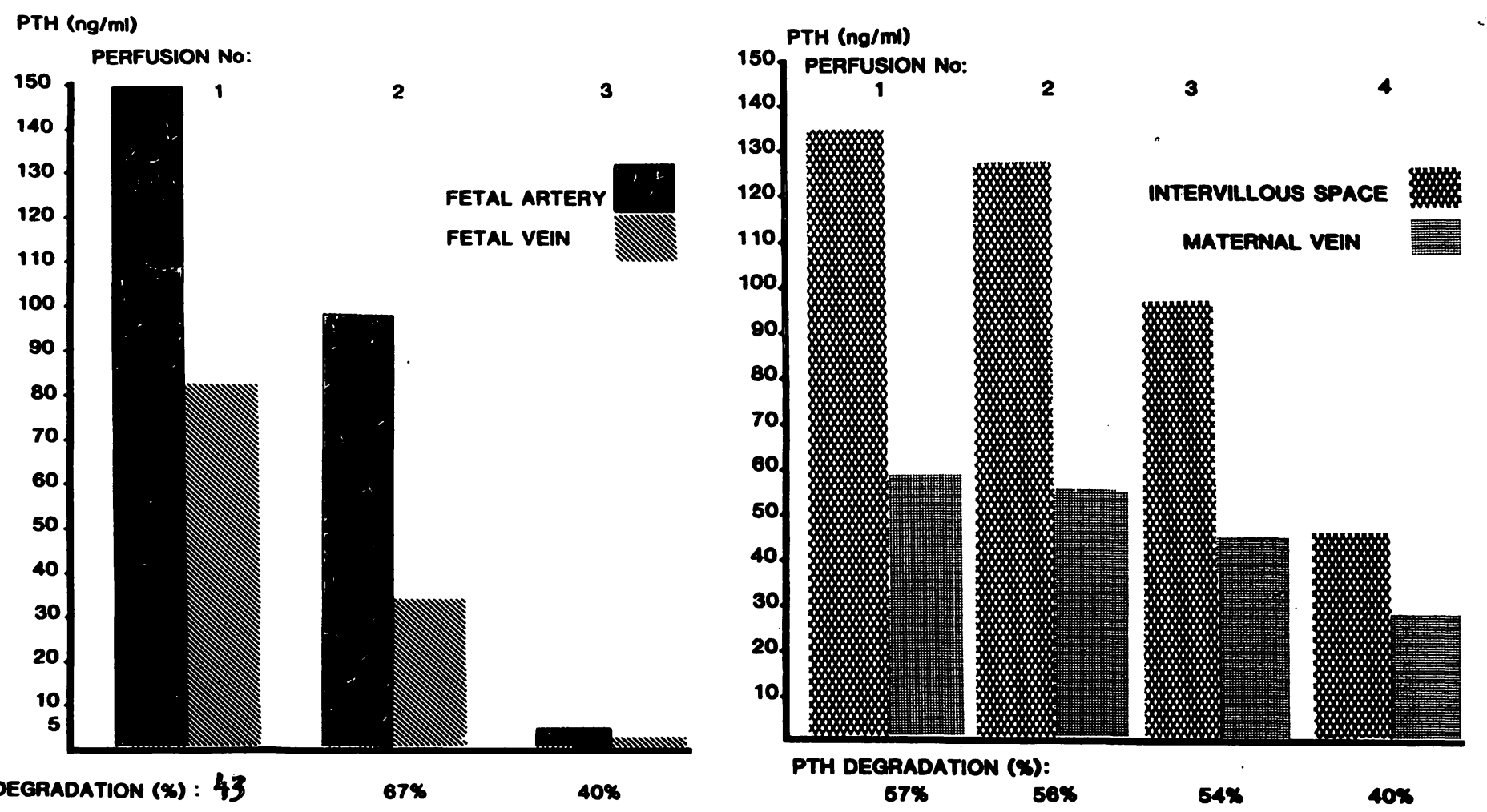

Figure 3. Degradation of PTH (amino acids 35-84) during passage from the placental fetal artery to the fetal vein and through the intervillous space to the maternal vein. 
Table I. Concentrations of parathyroid hormone (PTH) (amino acids 35-84) in maternal venous plasma at delivery, plasma of umbilical cord vessels and in venous blood of normal adult voluntees.

\begin{tabular}{lcc}
\hline & PTH (ng/ml) & range \\
\hline Maternal plasma & median & $0.7-3.3$ \\
Umbilical artery & 1.8 & $0.7-3.0$ \\
Umbilical vein $(\mathrm{n}=40)$ & 1.4 & $0.5-2.9$ \\
Correlation between maternal and umbilical cord vein concentrations & 1.2 & $\mathrm{r}=0.682$ \\
& & $\mathrm{P}<0.001$ \\
P-values of umbilical arterial-venous difference & $\mathrm{P}<0.001$ \\
\hline Control values of adults $(\mathrm{n}=169)$ & & $0.5-3.4$ \\
\hline
\end{tabular}

cantly lower than the maternal values at delivery $(P<0.001)$. There was a significant correlation between maternal and venous cord plasma PTH $(r=0.682, \mathrm{P}<0.001)$ (figure 4).

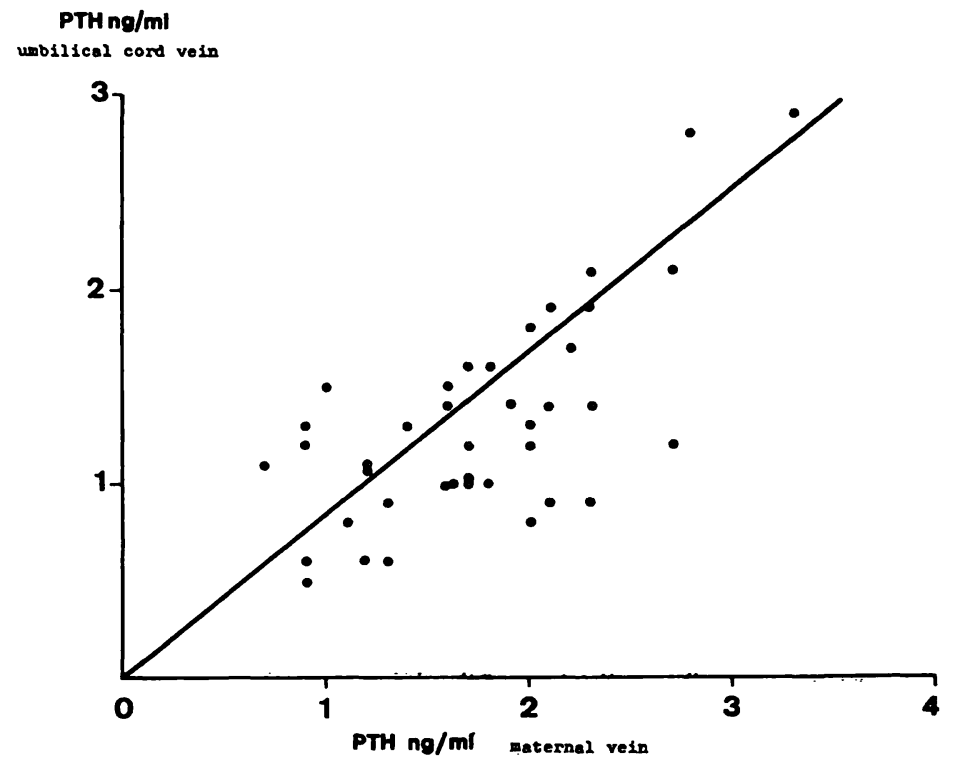

Figure 4. Correlation between PTH (amino acids $35-84)$ concentrations in maternal and venous cord plasma.

\section{Discussion}

The permeability of mammalian placenta for PTH has been studied in vivo by different investigators. No transfer was found in animal experiments by Hoskin et al [16], SMITH et al [30], Lehrmann et al [18], Care et al [9], Fleischman et al [13], NORTHROP et al [22], and ERENBERG et al [11]. In contrast, when the data of SMITH et al [30] and NORTHROP et al [22] are reconsidered, it is evident that in some experiments the PTH concentrations in the fetus increased after injection of PTH into the pregnant animal and vice versa. However, the amounts of transferred hormone were very small and inconsistent and the authors concluded that PTH did not cross the placental barrier in either direction.

Intact PTH (amino acids 1-84) has a molecular weight of above 10000 . In the circulation, it is rapidly cleaved through receptors in the periphery. Circulating PTH, represents a heterogenous mixture of polypeptides with different molecular weights [8]. The low molecular weight fragments may traverse the placenta [28] easier than the high molecular fragments. In our studies we have demonstrated placental transfer of three different PTH fragments with molecular weights between 1500 and 7000 (figure 2).

Conversely, we have also observed up to $67 \%$ PTH (amino acids 35-84) degradation during the passage through the placenta. This could explain the low amount of PTH transfer in the previously described animal experiments.

Placental transfer is dependent upon various factors, such as fat solubility, degree of ionization, possible existence of a transport mechanism and the PTH transfer also from calcium 
homeostasis. All these variables are not present under our experimental conditions.

This hypothesis of the PTH transfer is in agreement with the measurements of PTH in plasma of maternal and umbilical cord vessels. We detected immunoassayable PTH in all maternal venous and arterial and venous umbilical cord plasma samples with a highly significant correlation between maternal and umbilical cord venous plasma concentrations (figure 4) [3]. All arterial and venous cord umbilical plasma values were lower than the maternal PTH values but within the range of normal adult values. These results are in accordance with the data of SCHEDEWIE et al [26], LEQUIN et al [17], TSANG et al [31], Watney et al [32], and PITKIN et al [23]. On the contrary, FANCONI et al [12], DAVID et al [10], Root et al [25], FleischmanN et al [13], Reitz et al [24], HillmanN et al [15], and WIELAND et al [33] either could not detect PTH in cord blood or observed only very low concentrations.

The discrepancies of data from different investigators could be explained by the use of different antisera. The specific antisera in the radioimmunosassy determine different PTH fragments [2]. The lack of a PTH standard of human origin, the immunological differences between species, the fact that genuine glandular hormone is immunologically different from secreted hormone, and the lack of international standard material all may account for the divergence of results.

In this study we observed significantly higher PTH levels in the umbilical cord artery than in the vein. Norris [21], MosCa [20], and ANAST [1] demonstrated that the fetal parathyroid glands develop during the first three embryonic months. SCOTHORN [29] showed that parathyroid function in the human fetus may be present as early as twelve to thirteen weeks of gestation. In accordance with these authors, our results prove that the fetus at term secretes PTH into its plasma.

In summary the present study demonstrates the placental transfer of different PTH fragments in an in vitro perfusion model. The perfused and transferred fragments were identical. It was also observed, that human placenta, similar to the kidney and liver [6], degraded the hormone. The measured PTH concentrations in the umbilical cord vessels plasma as well as the significant correlation between PTH values in maternal and umbilical cord venous plasma supported the in vitro findings and led to the conclusion that PTH transfer also occurs in vivo.

The permeability of the human placenta for PTH fragments and its capacity to degrade the hormone suggests the importance of this organ in the calcium homeostasis during pregnancy.

\section{Summary}

We investigated the in vitro transfer of three parathyroid hormone (PTH) fragments (amino acids 35-84, 44-68 and 65-84) through human placenta at term. The perfused and transferred fragments were measured radioimmunologically and identified by three different methods: high-pressure-liquid chromatography (HPLC), preparative flat-bed electrofocussing (PEGG), and gel filtration (GF). The study demonstrated that PTH fragments traverse the human placenta. The transferred and perfused fragments were identical. We observed a signifi- cant degradation of the perfused hormone during the passage through the placenta in both fetal and maternal directions.

In addition, we measured the PTH concentrations on forty samples of maternal and umbilical cord artery and vein plasma obtained immediately after delivery. A highly significant correlation of PTH concentrations in the maternal and umbilical cord vessels was observed. These findings support the contention that human placenta at term is permeable for PTH fragments.

Keywords: Degradation, parathyroid hormone, placenta, transfer. 


\title{
Zusammenfassung
}

\section{Plazentarer Transport von Parathormon}

Die Durchlässigkeit der menschlichen Plazenta wurde mit Hilfe einer in vitro Perfusion untersucht. Dabei konnte bei Perfusionen mit PTH Fragmenten (35-84), (44-68) und (65-84) ein Transfer nachgewiesen werden. Durch die Auftrennung des maternal venösen und fetal venösen Perfusats mittels Gelchromatographie, isoelektrischer Fokussierung und Reversed-Phase Chromatographie konnte gezeigt werden, daß die PTH-Fragmente größtenteils unverändert durch die Plazentaschranke hindurchgelangten. Bei der Durchführung der plazentaren Perfusion wurde eine Abnahme der Hormonkonzentration beobachtet.

Bei 40 gesunden Müttern wurde nach der Entbindung Parathormon im peripheren Venenblut sowie im Blut der Nabelschnurarterie und -vene des Kindes bestimmt. Zwischen den Parathormon-Konzentrationen im Blut der Mutter und denen der Nabelschnurvene bestand eine signifikante Korrelation. Auch dies ist mit der Annahme eines diaplazentaren Transports von humanen Parathormon in vivo vereinbar.

Schlüsselwörter: Abbau, Parathormon, Plazenta, Transport.

\begin{abstract}
Résumé
Transfert placentaire de l'hormone parathyrö̈dienne Nous avons étudié le transfert in vitro de 3 fragments de l'hormone parathyroïdienne ou P. T. H. (acides aminés $35-84,44-68$, et $65-84$ ) à travers le placenta humain à terme. Les mesures des fragments perfusés et transférés étaient effectuées par radioimmunologie et leurs identifications réalisées par trois méthodes différentes: chromatographie en phase liquide à haute pression (H. P. L. C.), électroconcentration préparatoire (P. E. G. G.) et filtration sur GEL (G. F.). Les résultats montrent que les fragments de $P$. T. H. traversent le placenta humain. Les fragments transférés et ceux perfusés sont identiques.
\end{abstract}

Nous avons également observé une dégradation significative de l'hormone perfusée au cours du passage placentaire que ce soit en direction du fœtus ou de la mère. En outre, nous avons mesuré les concentrations de P. T. H. dans quarante échantillons de plasma prélevés immédiatement après l'accouchement chez la mère et au niveau de l'artère et de la veine ombilicales. Une corrélation hautement significative a été observée entre les concentrations de P. T. H. maternelles et dans les vaisseaux ombilicaux. Ces données appuient l'affirmation que le placenta humain à terme est perméable pour les fragments de $P$. T. $H$.

Mots-clés: Dégradation, hormone parathyroïdienne, placenta, transfert.

Acknowledgements: This study was supported by Deutsche Forschungsgemeinschaft $\mathrm{Ba} 807 / 2-1$.

\section{References}

[1] ANAST C: Development of the normal embryonic, fetal, and neonatal parathyroid. In: GARDNER LI (ed): Endocrine and Genetic Diseases of Childhood. Saunders, Philadelphia-London 1975

[2] ARnaud CD, R Goldsmith, P Bordier, G SizemoRE, J LARSEN, L GILKINSON: Influence of immunoheterogenity of circulating parathyroid hormone on results of radioimmunoassays of serum in man. Am J Med 56 (1974) 785

[3] Balabanova S, F Pohlandt, WM Teller: Correlation between parathyroid hormone and calcitonin concentrations in samples of maternal and umbilical cord vessel plasma in man. J Endocrinol [Suppl] 94 (1982) 10
[4] Balabanova S, F Pohlandt, I Henrichs, WM TELLER: Diaplacental transfer of parathyroid hormone and calcitonin in an in vitro placental perfusion model. J Endocrinol [Suppl] 94 (1982) 39

[5] Balabanova S, T Lang, aS Wolf, I Henrichs, G GaEdicke, U VetTer, WM Teller: Placental transfer of parathyroid hormone. Pediatr Res 6 (1985) 159

[6] BeCKer FO, F Buchanan, M Rashs: Parathyroid hormone degradation studies in maternal and fetal rat tissues by radioimmunoassays. Horm Metab Res 6 (1974) 407

[7] BronsKy D, RT KIAMKo, R MoNCADA, IM RosenTHAL: Intrauterine hyperparathyreodism secondary 
to maternal hypoparathyreodism. Pediatrics 42 (1968) 606

[8] CANTERBURY JM, E Reiss: Multiple immunoreactive molecular forms of parathyroid hormones in human serum. Proc Soc Exp Biol Med 140 (1972) 1393

[9] Care AD, DW Picard, JM Garel, JP Varlet, S TOMLINSON, JLH O'RIORDAN: Autonomy of calcium homeostasis in the sheep foetus. Horm Metab Res 7 (1975) 103

[10] David L, CS ANAST: Calcium metabolism in newborn infants. J Clin Invest 54 (1974) 287

[11] ERenberg A, MM Weinstein, IW Chen, RC TSANG: Placental impermeability to parathormone (PTH) I-125 in the ewe. Pediatr Res 12 (1978) 394

[12] Fanconi A, A Prader: Transient congenital idiopathic hypoparathyroidism. Helv Paediatr Acta 4 (1967) 342

[13] Fleischman AR, S Lerman, GK OAKes, MF EPSTEIN, RA CHEZ, DH MINTZ: Perinatal primate parathyroid hormone metabolism. Biol Neonate 27 (1975) 40

[14] Henrichs I, J Brandner, A Wolf, WM Teller: Fetomaternal transfer of glucose in human placenta: Relation to fetal blood pressure. Pediatr Res 15 (1981) 1567

[15] Hillman LS, S Rojanasathit, E Slatopolsky, JG HADDAD: Serial measurements of serum calcium, magnesium, parathyroid hormone, calcitonin, and 25-hydroxy-vitamin D in premature and term infants during the first week of life. Pediatr Res 11 (1977) 739

[16] Hoskins FM, FF SNYDER: The placental transmission of parathyroid extract. Am J Physiol 104 (1933) 530

[17] LeQuin RM, WHL Hackeng, W Schopman: A radioimmunoassay for parathyroid hormone in man. Acta Endocrinol (Copenh) 64 (1970) 655

[18] Lerman S, AR Fleischman, GK OAKes, WF EPSTEIN, RA CHEZ, DH MinTz: The role of parathyroid hormone in fetal and neonatal calcium homeostasis. Clin Res 22 (1974) 474 A

[19] Meinert E: Fall von Tetanie in der Schwangerschaft, entstanden nach Kropfoperation. Arch Gynecol 5 (1898) 446

[20] Mosca L: Le paratiroidi del neonato umano. Biol Lat (Milano) 8 (1955) 1331

[21] NoRRIS EN: Anatomical evidence of prenatal function of the human parathyroid glands. Anat Rec 97 (1946) 129
[22] NORTHROP G, HR MISENHIMER, FO BECKER: Failure of parathyroid hormone to cross the nonhuman primate placenta. Am J Obstet Gynecol 129 (1977) 449

[23] Pitkin RM, DP CRuikshank, CW Schauberger, A ReYNolds, GA Williams, GK HaRgIS: Fetalcalcitropic hormone and neonatal calcium homeostasis. Pediatrics 66 (1980) 77

[24] Reitz RE, TA DAANe, JR Woods, RL Weinstein: Calcium, magnesium, phosphorus, and parathyroid hormone interrelationships in pregnancy and newborn infants. Obstet Gynecol 50 (1977) 701

[25] Root A, A Gruskin, RM Reber, A STOPA, GBS DUCKETT: Serum concentrations of parathyroid hormone in infants, children, and adolescents. J Pediatr 85 (1974) 329

[26] SCHEDEWIE HK, WD Odell, DA Fischer, SR KRUTZIK, M Dodge, L Cousins, WP FISER: Parathormone and perinatal calcium homeostasis. Pediatr Res 13 (1972) 1

[27] Schneider H, M Panigel, J Dancis: Transfer across the perfused human placenta of antipyrine, sodium, and leucine. Am J Obstet Gynecol 114 (1972) 822

[28] SCHREINER WE: Die plazentaren Funktionen und ihre Störungen. Gynecologia 161 (1966) 372

[29] SCOTHORN RJ: Functional capacity of fetal parathyroid glands with reference to their clinical use as homografts. Ann NY Acad Sci 120 (1964) 669

[30] SMith FG JR., DP AleXander, RM BUCKLe, HG BRITTON, DA NoXon: Parathyroid hormone in foetal and adult sheep: The effect of hypocalcaemia. J Endocrinol 53 (1972) 339

[31] Tsang RC, IW Chem, MA Friedman, I Chen: Neonatal parathyroid function: role of gestational age and postnatal age. J Pediatr 83 (1973) 728

[32] WATHEY PJ, BT RUDD: Calcium metabolism in pregnancy and in the newborn. Br J Obstet Gynaecol 81 (1974) 210

[33] Wieland P, JA Fischer, U Treschel, HR Roth, K Vetter, H Schneider, A Hich: Perinatal parathyroid hormone, vitamin D metabolites, and calcitonin in man. Am J Physiol 239 (1980) 385

Received September 30, 1985. Accepted January 12, 1986.

Dr. Svetla Balabanova Univ.-Kinderklinik Prittwitzstr. 43 7900 Ulm Fed. Rep. Germany 